\title{
Pumpkin seed oil alleviates oxidative stress and liver damage induced by sodium nitrate in adult rats: biochemical and histological approach
}

\author{
Meriem Rouag ${ }^{1}$, Salma Berrouague ${ }^{1}$, Nesrine Djaber ${ }^{1}$, Taha Khaldi ${ }^{1}$, Mahieddine Boumendjel ${ }^{1}$, \\ Faiza Taibi ${ }^{1}$, Cherif Abdennour ${ }^{2}$, Amel Boumendjel ${ }^{1}$, Mahfoud Messarah $^{1}$
}

1. Laboratory of Biochemistry and Environmental Toxicology, Department of Biochemistry, Faculty of Sciences, University Badji Mokhtar-Annaba, 23000, Annaba, Algeria.

2. Laboratory of Animal Ecophysiology, Department of Biology, Faculty of Sciences, University Badji MokhtarAnnaba, 23000, Annaba, Algeria

\begin{abstract}
Background: Nitrate $\left(\mathrm{NO}_{3}\right)$ is the most common chemical contaminant in the world's ground water aquifer. Oxidative stress has been proposed as a possible mechanism involved in $\mathrm{NO}_{3}$ toxicity on non-target organism.

Objectives: The current study aimed to elucidate the potential protective effect of Telfairia occidentalis (pumpkin seed oil, PSO) against hepatotoxicity induced by sodium nitrate.

Methods: Wistar rats were exposed either to $\mathrm{NaNO}_{3}(200 \mathrm{mg} / \mathrm{kg} \mathrm{bw})$ in drinking water in drinking water, or to $4 \mathrm{ml} \mathrm{PSO} / \mathrm{kg}$ bw by gavage or to their combination. Oxidative stress parameters, biochemical biomarkers and liver histopathological examination were determined.

Results: Our data showed that the exposure of rats to $\mathrm{NaNO}_{3}$ caused significant changes of some haematological parameters compared to the control. In addition, there was a significant elevation of the levels of biochemical markers as that of aspartate aminotransferase, alanine aminotransferase, alkaline phosphatase and lactate dehydrogenase when compared with the control. Furthermore, exposure of rats to $\mathrm{NaNO}_{3}$ induced liver oxidative stress as indicated by the increase of malondialdehyde, progressive oxidation of protein products and protein carbonyl levels. In addition, a reduction in anti-oxidant status (catalase, glutathione peroxidase, glutathione-S-transferase and superoxide dismutase, reduced glutathione and vitamin C) was observed.

Conclusion: Co-administration of PSO to the $\mathrm{NaNO}_{3}$ restored most parameters cited above to near-normal values. Therefore, the present investigation revealed the ability of PSO to attenuate $\mathrm{NaNO}_{3}$-induced oxidative damage.

Keywords: Sodium nitrate, Telfairia occidentalis, pumpkin seed oil, hepatotoxicity, oxidative stress, protection, anti-oxidant status, rat.

DOI: https://dx.doi.org/10.4314/ahs.v20i1.48

Cite as: Ronag M, Berronague S, Djaber N, Khaldi T, Boumendjel M, Taibi F, et al. Pumpkin seed oil alleviates oxidative stress and liver damage induced by sodium nitrate in adult rats: biochemical and histological approach. Afri Health Sci. 2020;20(1):413-25. https:/ / dx.doi.org/10.4314/ abs.v20i1.48
\end{abstract}

\section{Corresponding author:}

Mahfoud Messarah, Laboratory of Biochemistry and Environmental Toxicology, Department of Biochemistry, Faculty of Sciences, University Badji Mokhtar-Annaba, 23000, Annaba, Algeria.

Tel.: +21338 876110

Fax: +21338 876110

E-mail address: mahfoud.messarah@univ-annaba.dz; mmessarahdz@yahoo.fr

\section{Introduction}

Nitrate exposure may be considered as a causative factor in the context of the environmental pollutants. Drinking water is the most common pathway through which the population is exposed to nitrate ${ }^{1}$. In recent years, considerable attention has been paid to the intensive use of nitrates as agricultural fertilizers that reach humans and animals by different routes ${ }^{2}$. In fact, it penetrates through soil and remains in ground water for decades ${ }^{3}$. Moreover, nitrate levels in drinking water should not exceed $50 \mathrm{mg} / \mathrm{L}$ as recommended by the World Health Organization guideline ${ }^{4}$. 
Nitrate is relatively non-toxic ${ }^{5}$, but approximately $5 \%$ of all ingested nitrate is converted by microflora in the gastrointestinal tract to the most toxic nitrite ${ }^{2}$, which binds to haemoglobin to form methemoglobin. Thus, children are particularly susceptible to developing methemoglobinemia ${ }^{3}$. The risk of nitrate toxicity mainly belongs to formation of reactive oxygen species, free radicals as well as other toxic transient compounds, such as peroxynitrite, hydrogen peroxide and superoxide anion, which interrupt the equilibrium between oxidants and anti-oxidant, causing the so-called oxidative stress ${ }^{6}$. When produced in excess, ROS could damage critical molecules such as lipids, proteins and nucleic acid bases, thus resulting in cell cycle arrest and apoptosis ${ }^{7}$. Its presence may cause metabolic, and physiological modifications in hepatic cells ${ }^{8}$. Diet supplementation with natural anti-oxidants can serve as a type of preventive medicine, for this reason, research works dealing with the determination of natural antioxidant sources are important ${ }^{9}$. Therefore, the number of reports focussing on the identification, isolation and testing of natural anti-oxidants from plants has increased immesely during the last decade?

Fluted pumpkin Telfairia occidentalis is a species of cucurbitaceae family in the tropics and largely consumed in some African countries ${ }^{10}$ and frequently used as functional food or medicine ${ }^{11}$. The health benefits of pumpkin seeds are attributed to their macro- and microconstituents as proteins, triterpenes, lignans, phytosterols, polyunsaturated fatty acids, anti-oxidative phenolic compounds, carotenoids, tocopherol and minerals ${ }^{12}$.

Pumpkin seed oil is used in the preparation of some salads, giving them a very pleasant taste ${ }^{13}$. It is also an extraordinarily rich source of diverse bioactive compounds having functional properties used as edible oil or as a potential nutraceutical. In recent years, several studies have highlighted the medical properties of pumpkin seed oil known as strongly dichromatic viscous oil ${ }^{14}$.

The aim of the present study is to elucidate the possible beneficial effects of pumpkin seed oil in preventing sodium nitrate induced toxicity by evaluating biochemical, hematological and oxidative stress parameters as well as the liver histological architecture of wistar rats.

\section{Materials and methods}

\section{Chemicals}

All chemical products used in this study were purchased from Sigma Chemical Co. (St. Louis, France).

\section{Plant}

Hemani pumpkin seed oil was provided from a local market. Commercialised Oil was prepared by pressing roasted pumpkin seeds in Pakistan.

\section{Determination of total phenols}

Total phenolic compounds were determined using the Folin-Ciocalteau reagent according to the method described by Bouaziz et $\mathrm{al}^{15}$. The optical density was measured at $\lambda$ $=727 \mathrm{~nm}$ by using the spectrophotometer (OPTIZEN 2120UV). The total phenolic content is expressed as milligram of gallic acid (GA) equivalent per gram of PSO.

\section{Total flavonoid contents}

Total flavonoids were measured by a colorimetric assay adopted by Zhishen et $\mathrm{a}^{16}$. The absorbance against blank was determined at $510 \mathrm{~nm}$. The total flavonoid contents were expressed as milligram quercetin equivalents $(\mathrm{QE}) / \mathrm{g}$ extract.

\section{Condensed tannin contents}

The method of Julkunen-Tiitto was applied to measure condensed tanins at $500 \mathrm{~nm}$ after $15 \mathrm{~min}$. Total tannin contents were expressed as $\mathrm{mg}$ catechin equivalent $(\mathrm{C}) / \mathrm{g}$ of $\mathrm{PSO}^{17}$.

\section{Determination of antioxidant activity DPPH radical scavenging assay}

DPPH (1,1-diphenyl-2-picrylhydrazyl) radical-scavenging effect was evaluated following the procedure described in a previous study ${ }^{18}$. The absorbance was read against a blank at $517 \mathrm{~nm}$. The inhibition of free radicals DPPH in percentage (IP \%) was calculated as follows: IP $\%=[(\mathrm{Ab}-$ lank -Ablank)/Ablank] $\times 100$. The anti-oxidant activities of PSO were expressed as IC50, the amount of antioxidant necessary to decrease the initial concentration of DPPH by $50 \%$. The lower IC50 values indicate a higher antioxidant activity. The synthetic anti-oxidants butylated hydroxytoluene (BHT) and ascorbic acid were used as positive controls. 


\section{Total anti-oxidant capacity by phosphomolybdenum method}

The total antioxidant capacity was based on the reduction of ammonium molybdate (IV) to ammonium molybdate (V) by the sample and the subsequent formation of green phosphate/Mo (V) compounds with a maximum absorption at $695 \mathrm{~nm}^{19}$.

\section{Total antioxidant capacity by ABTS method}

The total antioxidant capacity of PSO was determined by the modified method proposed by Turoli et al ${ }^{20}$. The stock solution of the ABTS radical was prepared by dissolving $38.4 \mathrm{mg}$ of 2,2'-azinobis (3-ethylbenzthiazoline-6-acid) (ABTS) in potassium persulfate solution $(2.45 \mathrm{mM})$, and the mixture was dark stored for 12 hours. The working solution was obtained by diluting the stock solution of the ABTS radical cation with methanol to obtain an absorbance of $0.7 \pm 0.002$ at $730 \mathrm{~nm}$.

\section{Animals}

Male Wistar rats (fifteen weeks old, weighing between 200 and 260g), obtained from Pasteur institute (Algiers) were used for the experimental procedures. Animals were acclimated for 2 weeks under the same laboratory conditions of photoperiod, an average relative humidity of $60 \%$ and room temperature of $23 \pm 2^{\circ} \mathrm{C}$. Food (standard food, supplied by the "ONAB, Bejaia", Algeria) and water were available ad libitum.

\section{Experimental design}

Rats were randomly divided into four groups of ten animals each $(\mathrm{n}=10)$. The first group served as a control. The second group was treated with sodium nitrate (200 $\mathrm{mg} / \mathrm{kg}$ body weight / day) in drinking tap water throughout the experimental period $(28 \text { days })^{3}$, while the third group was treated with pumpkin seed oil daily by oral gavage ( $4 \mathrm{ml} / \mathrm{kg}$ body weight / day) 13 . The fourth group received a combination of $\mathrm{NaNO} 3$ and pumpkin seed oil in the same way as in group II and III. Body weight, water and food consumption were monitored during treatment. All protocols used in this study were approved by PNR/ SF 08/2012 and by the Ethical Committee of Directorate General for Scientific Research and Technological Development at Algerian Ministry of Higher Education and Scientific Research.

\section{Blood collection}

At the end of the experimental period, animals were fasted overnight, then weighted and sacrificed by cervical decapitation. Blood samples were immediately collected into two groups of ice-cold polypropylene tubes. While the first one contained ethylenediaminetetracetic acid (EDTA) used for the determination of haematological parameters, the second group (had no anticoagulant) was centrifuged at 3,000 rpm for $15 \mathrm{~min}$ at $4^{\circ} \mathrm{C}$ and then used for the measurement of biochemical parameters. Serum samples were stored at $-20^{\circ} \mathrm{C}$.

\section{Preparation of liver homogenates}

Liver samples were quickly removed, washed in $0.9 \%$ $\mathrm{NaCl}$ solution and weighed after the careful removal of the surrounding connective tissues, and then $1 \mathrm{~g}$ was homogenized in $2 \mathrm{ml}$ of buffer solution ( $50 \mathrm{~mm}$ Tris, $150 \mathrm{~mm}$ $\mathrm{NaCl}, \mathrm{pH}$ 7.4) in ice-cold condition. Homogenates were centrifuged at 10,000 rpm for 15 min at $4{ }^{\circ} \mathrm{C}$ (Presvac DCS-16RTV); the supernatants were divided into aliquots and then stored at $-20^{\circ} \mathrm{C}$.

\section{Haematological variables}

Haematological parameters (red blood cells, white blood cells, haemoglobin, haematocrit, platelets) were evaluated by Automatic Blood Cell Counter (PCE-210N).

\section{Biochemical analysis}

Total proteins, glucose, bilirubin, aspartate aminotransferase (AST), alanine aminotransferase (ALT), alkaline phosphatase (ALP) and lactate dehydrogenase (LDH) were assessed using Spinreact Laboratory diagnostic kits, Spain.

\section{Nitric oxide serum levels}

The level of nitric oxide $(\mathrm{NO})$ in serum was measured by assaying total nitrate/nitrite, as described by Green et $\mathrm{al}^{21}$. The subsequent absorbance was determined using an ELISA reader (mindray MR-96A). The concentration of $\mathrm{NO}$ was determined using a standard curve prepared from $\mathrm{NaNO} 2$.

\section{Liver MDA, PCO and AOPP measurement}

Lipid peroxidation in liver was realised by measuring malondialdehyde (MDA) levels according to the method of Esterbauer et al ${ }^{22}$. The absorbance of TBA-MDA 
complex was recorded at $530 \mathrm{~nm}$. The MDA content was expressed as nmol MDA/mg proteins.

Protein carbonyl (PCO) levels in liver tissue were determined using the 2,4-Dinitrophénylhydrazine (DNPH) method by Reznick and Packer ${ }^{23}$. The absorbance of the sample was read against a blank with guanidine at 370 nm. Protein Carbonyl (PCO) contents was calculated based on the molar extinction coefficient of DNPH $(\varepsilon$ $=2.2104 \mathrm{~cm} \mathrm{M}-1$ ) and expressed as $\mathrm{nmol} / \mathrm{mg}$ proteins.

Liver tissue contents of advanced oxidation protein products (AOPP) were determined at $340 \mathrm{~nm}$ according to the method of Kayali et $\mathrm{al}^{24}$. The concentration of AOPP for each sample was calculated using the extinction coefficient of $261 \mathrm{~cm}-1 \mathrm{mM}-1$ and the results were expressed as $\mathrm{nmol} / \mathrm{mg}$ proteins.

\section{Estimation of liver enzymatic antioxidants}

Glutathione peroxidase (GSH-Px) activity was measured according to the procedure of Flohe and Gunzler ${ }^{25}$. The absorbance was recorded at $412 \mathrm{~nm}$ and the specific activity of this enzyme is expressed as $\mu \mathrm{mol} \mathrm{GSH} / \mathrm{mg}$ proteins.

Glutathione-S-transferase (GST) activity was measured by the method of Habig et $\mathrm{al}^{26}$. The 1-Chloro-2,4-dinitrobenzène (CDNB) was used as electrophilic substrate that binds to GSH with the participation of the enzyme and forms a colored GSH-substrate complex, detected at $340 \mathrm{~nm}$. The activity of GST was expressed in terms of nmol GST/min/mg proteins.

Catalase activity (CAT) was measured using the method of $\mathrm{Aebi}^{27}$. It is based on the ability of the enzyme to induce the disappearance of hydrogen peroxide monitored by following the decrease in the absorbance at $240 \mathrm{~nm}$ for $1 \mathrm{~min}$. CAT activity was calculated in terms of $\mu \mathrm{mol}$ $\mathrm{H}_{2} \mathrm{O}_{2}$ consumed $/ \mathrm{min} / \mathrm{mg}$ of proteins.

Superoxide dismutase (SOD) specific activity was determined according to the method described by Beyer and Fridovich $^{28}$. One unit of SOD activity corresponded to the amount of enzyme required to cause $50 \%$ inhibition of Nitro blue tetrazolium (NBT) reduction at $560 \mathrm{~nm}$. SOD activity was expressed as units'/mg proteins.

\section{Estimation of liver non-enzymatic antioxidants}

Reduced glutathione (GSH) concentrations in liver homogenates were performed with the method described by Ellman ${ }^{29}$ modified by Jollow et $\mathrm{al}^{30}$. It is based on the development of a yellow color when DTNB [5,5-dithio-bis-(2-nitrobenzoic acid)] is added to compounds containing sulfhydryl groups. The absorbance was recorded at $412 \mathrm{~nm}$. Total GSH content was expressed as nmol GSH/mg proteins.

Liver vitamin $\mathrm{C}$ level was performed as described by Jacques-Silva et $\mathrm{al}^{31}$. The absorbance was measured at 540 $\mathrm{nm}$. The data are expressed as $\mu \mathrm{mol} / \mathrm{mg}$ proteins.

\section{Histopathological examinations}

Liver samples were dissected and immediately fixed in $10 \%$ formalin solution for histopathological analysis. The organ tissues were processed using a graded ethanol series, and embedded in paraffin. The paraffin sections were cut into $5 \mu \mathrm{m}$ (Microtome Leica RM 2125RTS) thick slices and stained with hematoxylin and eosin for light microscopic examination.

\section{Statistical analysis}

All data were expressed as mean \pm SD for 10 rats of each group using Microsoft Excel (2016). Significant differences between group's means were determined by Student's t test. The statistical significance was taken at $\mathrm{p} \leq 0.05$.

\section{Results}

Polyphenolic contents and antioxidant activity of PSO

Results for the quantitative determination of total phenols, flavonoids and tannins contents of PSO are shown in Table 1. The assessment of the DPPH showed an IC50 value $(\mu \mathrm{g} / \mathrm{ml}$ PSO), total antioxidant capacity by phosphomolybdeneum (mg Vit C/g extract) and ABTS radical scavenging (mg trolox equivalent/g PSO). 
Table 1. Polyphenols, flavonoids, tannins contents and antioxidant activity of PSO (DPPH, CAT and ABTS).

\begin{tabular}{ll}
\hline Parameters & Contents \\
\hline Polyphenols (mg gallique acid equivalent / g of PSO) & $1.45 \pm 0.01$ \\
Flavonoids (mg quercetin acid equivalents /g PSO) & $1.35 \pm 0.01$ \\
Tannins (mg catechin equivalents /g PSO) & $0.98 \pm 0.01$ \\
Percentage scavenging concentration (mg/ml) on DPPH radical & $187.56 \pm 5.78$ \\
CAT (mg Vit C/g PSO) & $3.78 \pm 0.22$ \\
ABTS (mM Trolox E /g PSO) & $1.45 \pm 0.01$ \\
\hline
\end{tabular}

Values are means \pm SEM, triplicate for each parameter.

\section{Effect of treatments on body and liver weight}

Changes in body, relative and absolute liver weights are presented in Table 2. Our results showed a significant decrease in the body weigt of $\mathrm{NaNO}_{3}$ group $(-8.79 \%)$. Their absolute and relative liver weight was increased sig- nificantly by $(+13.77 \%)$, and $(+25 \%)$, respectively, when compared to that of the control. However, in $\mathrm{NaNO}_{3} /$ PSO treated rats, a significant decrease in absolute and relative liver weight compared to $\mathrm{NaNO}_{3}$ were registered $(-11 \%$ and $-15.6 \%$ respectively).

Table 2. Body weight, absolute and relative liver weight, food intake, water consumption of control and treated rats with $\mathrm{NaNO}_{3}$, PSO or their combination $\left(\mathrm{NaNO}_{3} / \mathrm{PSO}\right)$ during 28 days.

\begin{tabular}{|c|c|c|c|c|}
\hline Parameters and treatments & $\begin{array}{c}\text { Control } \\
(\mathrm{n}=10)\end{array}$ & $\begin{array}{l}\mathrm{NaNO}_{3} \\
(\mathrm{n}=10)\end{array}$ & $\begin{array}{l}\text { PSO } \\
(n=10)\end{array}$ & $\begin{array}{c}\mathrm{NaNO}_{3} / \mathrm{PSO} \\
(\mathrm{n}=10)\end{array}$ \\
\hline Initial body weights $(\mathrm{g})$ & $265.33 \pm 4.81$ & $265.3 \pm 3.63$ & $265.16 \pm 4.58$ & $265 \pm 4.67$ \\
\hline Final body weights $(\mathrm{g})$ & $300.57 \pm 5.22$ & $274.14 \pm 3.04^{* * *}$ & $290.125 \pm 6.48$ & $283.375 \pm 5.1$ \\
\hline Absolute liver weight (mg) & $7.04 \pm 0.19$ & $8.01 \pm 0.16^{* * 2}$ & $7.15 \pm 0.16^{\# \#}$ & $7.13 \pm 0.22^{\# \#}$ \\
\hline Relative liver weights & $2.36 \pm 0.09$ & $2.95 \pm 0.09^{* * *}$ & $2.43 \pm 0.07^{\# \#}$ & $2.5 \pm 0.1^{\# \#}$ \\
\hline Food intake(g/day/rat) & $19.77 \pm 0.05$ & $19.61 \pm 0.04^{* * *}$ & $18.35 \pm 0.17^{* * * \#}$ & $17.6 \pm 0.14^{* * * \#}$ \\
\hline water consumption (ml/day/rat) & $29.37 \pm 0.09$ & $29.39 \pm 0.07$ & $26.92 \pm 0.42^{* * * \# \#}$ & $27.63 \pm 0.37^{* * * \# \# \#}$ \\
\hline $\begin{array}{l}\text { Quantities of } \mathrm{NaNO}_{3} \text { ingested } \\
\text { (mg/day/rat) }\end{array}$ & $\begin{array}{c}--- \\
--1\end{array}$ & $77.90 \pm 0.21$ & $\begin{array}{c}---- \\
-1\end{array}$ & $73.22 \pm 0.96$ \\
\hline
\end{tabular}

\section{Effect of treatments on food intake and water con- sumption}

The PSO and $\mathrm{NaNO}_{3} / \mathrm{PSO}$ groups induced significant reduction in food intake $-7.08 \%$ and $-8.34 \%$ ) and water consumption $(-10.88 \%$ and $-5.92 \%)$ compared with the control rats. However, $\mathrm{NaNO}_{3}$ group had no effect on water consumption and significantly decreased food intake by -5 span style $=$ "font-family:'Times New Roman"'>. $26 \%$.

\section{Effects of treatments on haematological parameters} The treatment of animals with $\mathrm{NaNO}_{3}$ significantly decreased $\mathrm{RBC}, \mathrm{Hb}$ and $\mathrm{Ht}$ by $-11.41 \%,-20.39 \%$ ) and $-7.02 \%$, respectively, and considerably increased WBC count by $+62.12 \%$ in comparison to the control (Table $3)$. However, the administration of PSO alone caused a significant increase of WBC by $+10.7 \%$ as compared to the control. The PSO co-treatment $\left(\mathrm{NaNO}_{3}+\mathrm{PSO}\right)$ ameliorated these parameters when compared to $\mathrm{NaNO}_{3}$ group. 
Table 3. Hematological parameters in control and treated rats with $\mathrm{NaNO}_{3}$, $\mathrm{PSO}$ or their combination $\left(\mathrm{NaNO}_{3} / \mathrm{PSO}\right)$ during 28 days.

\begin{tabular}{lcccc}
\hline $\begin{array}{c}\text { Parameters and } \\
\text { treatments }\end{array}$ & $\begin{array}{c}\text { Control } \\
(\mathrm{n}=10)\end{array}$ & $\begin{array}{c}\mathrm{NaNO}_{3} \\
(\mathrm{n}=10)\end{array}$ & $\begin{array}{c}\mathrm{PSO} \\
(\mathrm{n}=10)\end{array}$ & $\begin{array}{c}\mathrm{NaNO}_{3} / \mathrm{PSO} \\
(\mathrm{n}=10)\end{array}$ \\
\hline $\mathrm{RBC}\left(10^{6} / \mu \mathrm{L}\right)$ & $9.55 \pm 0.23$ & $8.46 \pm 0.22^{* *}$ & $9.97 \pm 0.28^{\# \#}$ & $9.39 \pm 0.28^{\#}$ \\
$\mathrm{WBC}\left(10^{3} / \mu \mathrm{L}\right)$ & $9.53 \pm 0.3$ & $15.45 \pm 1.27^{* * *}$ & $8.51 \pm 0.34^{* \#}$ & $9.72 \pm 0.54^{\# \#}$ \\
$\mathrm{PLT}\left(10^{3} / \mu \mathrm{L}\right)$ & $332.5 \pm 20.87$ & $359.37 \pm 14.59$ & $333.62 \pm 16.37$ & $332.37 \pm 8.07$ \\
$\mathrm{Hb}(\mathrm{g} / \mathrm{dL})$ & $20.25 \pm 0.78$ & $16.12 \pm 0.53^{* * \#}$ & $20.45 \pm 1.45^{\# \#}$ & $20.11 \pm 0.92^{\# \#}$ \\
$\mathrm{HT}(\%)$ & $38.87 \pm 0.6$ & $36.14 \pm 0.35^{* * \#}$ & $39.57 \pm 0.99^{\# \#}$ & $38.2 \pm 0.61^{\# \#}$ \\
\hline
\end{tabular}

Values are means \pm SEM, n: number of animals in each group.

${ }^{*} \mathrm{p}<0.05,{ }^{* *} \mathrm{p}<0.01,{ }^{* * *} \mathrm{p}<0.001$ : significantly different from control group.

$\# \mathrm{p}<0.05, \# \mathrm{p}<0.01, \# \# \mathrm{p}<0.001$ : significantly different from $\mathrm{NaNO}_{3}$.

Effects of treatments on biochemical parameters

Compared to the control, $\mathrm{NaNO}_{3}$ treated animals had a significant increase in serum AST, ALT, ALP and LDH activities (Table 4). The administration of PSO alone caused a significant decrease of ALT and LDH activities compared to the control. In addition, the levels of serum glucose, total bilirubin and total proteins of $\mathrm{Na}$ $\mathrm{NO}_{3}$-treated rats were significantly increased. The com- bined treatment $\left(\mathrm{NaNO}_{3}+\mathrm{PSO}\right)$ restored all biochemical parameters studied.

\section{Effect of treatments in nitric oxide levels}

The treatment of rats with $\mathrm{NaNO}_{3}$ induced substantial increase of serum nitric oxide (NO), while the co-treatment preserved the NO at its normal levels (Table 4).

MDA, PCO and AOPP levels

Table 4. Biochemical parameters in control and treated rats with $\mathrm{NaNO}_{3}$, $\mathrm{PSO}$ or their combination $\left(\mathrm{NaNO}_{3} / \mathrm{PSO}\right)$ during 28 days.

\begin{tabular}{lcccc}
\hline $\begin{array}{l}\text { Parameters and } \\
\text { treatments }\end{array}$ & $\begin{array}{c}\text { Control } \\
(\mathrm{n}=10)\end{array}$ & $\begin{array}{c}\mathrm{NaNO}_{3} \\
(\mathrm{n}=10)\end{array}$ & $\begin{array}{c}\mathrm{PSO} \\
(\mathrm{n}=10)\end{array}$ & $\begin{array}{c}\mathrm{NaNO}_{3} / \mathrm{PSO} \\
(\mathrm{n}=10)\end{array}$ \\
\hline Glucose $(\mathrm{g} / \mathrm{L})$ & $0.92 \pm 0.03$ & $1.3 \pm 0.15^{*}$ & $0.84 \pm 0.02^{\# \#}$ & $0.85 \pm 0.03^{\# \#}$ \\
NO $(\mathrm{m} \mathrm{M} / \mathrm{L})$ & $1.61 \pm 0.06$ & $2.13 \pm 0.04^{* * *}$ & $1.69 \pm 0.07^{\# \#}$ & $1.8 \pm 0.03^{* \# \#}$ \\
Total bilirubin $(\mathrm{mg} / \mathrm{L})$ & $1.48 \pm 0.09$ & $2.18 \pm 0.17^{* *}$ & $1.54 \pm 0.13^{\# \#}$ & $1.71 \pm 0.09^{\#}$ \\
Total proteins $(\mathrm{g} / \mathrm{dL})$ & $75.75 \pm 1.07$ & $62.58 \pm 2.54^{* *}$ & $79.82 \pm 1.77^{\# \# \#}$ & $73.96 \pm 1.813^{\# \#}$ \\
AST (U/L) & $173.56 \pm 8.55$ & $223.45 \pm 12.28^{* *}$ & $163.53 \pm 7.18^{\# \#}$ & $189.48 \pm 9.04^{\#}$ \\
ALT (U/L) & $55.79 \pm 3.49$ & $79.5 \pm 2.73^{* *}$ & $40.99 \pm 1.72^{* * \# \# \#}$ & $62.53 \pm 3.04^{\# \#}$ \\
ALP (U/L) & $97.57 \pm 6.66$ & $140.88 \pm 9.91^{* *}$ & $99.65 \pm 6.03^{\# \#}$ & $105.61 \pm 5.61^{\#}$ \\
LDH (U/L) & $575.23 \pm 31.22$ & $772.4 \pm 31.53^{* *}$ & $457.5 \pm 37.48^{* \# \#}$ & $654.85 \pm 31.23^{\#}$ \\
\hline
\end{tabular}

Values are means \pm SEM, n: number of animals in each group.

${ }^{*} \mathrm{p}<0.05,{ }^{*} \mathrm{p}<0.01,{ }^{* * *} \mathrm{p}<0.001$ : significantlydifferent from control group.

$\# p<0.05, \# \# p<0.01, \# \# \mathrm{p}<0.001$ : significantly different from NaNO3.

As shown in Table 5, a considerable increase in MDA, PCO and AOPP contents of liver by $+105.13 \%,+47.34 \%$ and $+90.57 \%$, respectively, was observed in $\mathrm{NaNO}_{3}$ treated animals when compared to the control. The treatment with PSO alone caused a decrease in MDA and AOPP levels $(-27.62 \%$ and $-30.43 \%$, respectively) compared to the control. The co-administration of $\mathrm{NaNO}_{3}$ and PSO induced a significant amelioration of MDA, PCO and AOPP levels compared to the control. 
Table 5. MDA, PCO, AOPP and non-enzymatic antioxidant (GSH, vitamin C) levels in liver of control and treated rats with $\mathrm{NaNO}_{3}$, $\mathrm{PSO}$ or their combination $\left(\mathrm{NaNO}_{3} / \mathrm{PSO}\right)$ during 28 days.

\begin{tabular}{ccccc}
\hline Parameters and treatments & $\begin{array}{c}\text { Control } \\
(\mathrm{n}=10)\end{array}$ & $\begin{array}{c}\mathrm{NaNO}_{3} \\
(\mathrm{n}=10)\end{array}$ & $\begin{array}{c}\mathrm{PSO} \\
(\mathrm{n}=10)\end{array}$ & $\begin{array}{c}\mathrm{NaNO}_{3} / \mathrm{PSO} \\
(\mathrm{n}=10)\end{array}$ \\
\hline MDA (nmol/mg prot.) & $2.56 \pm 0.23$ & $5.25 \pm 0.17^{* * *}$ & $1.85 \pm 0.11^{* \# \#}$ & $3.15 \pm 0.28^{\# \#}$ \\
PCO (nmol/mg prot.) & $46.96 \pm 3.67$ & $69.18 \pm 4.92^{* *}$ & $46.38 \pm 3.75^{\# \#}$ & $57.14 \pm 1.91^{* \#}$ \\
AOPP ( $\mu$ mol/mg prot.) & $18.83 \pm 1.62$ & $35.88 \pm 2.14^{* * *}$ & $13.1 \pm 0.38^{* \# \# \#}$ & $21.02 \pm 3.65^{\# \#}$ \\
GSH (nmol/mg prot.) & $2.12 \pm 0.03$ & $1.71 \pm 0.08^{* *}$ & $2.14 \pm 0.03^{\# \#}$ & $2.03 \pm 0.05^{\#}$ \\
Vit C $(\mu \mathrm{mol} / \mathrm{mg}$ prot.) & $0.1 \pm 0.01$ & $0.06 \pm 0.01^{* *}$ & $0.15 \pm 0.02^{\# \#}$ & $0.1 \pm 0.01^{\#}$ \\
\hline
\end{tabular}

Values are means \pm SEM, n: number of animals in each group.

${ }^{*} \mathrm{p}<0.05,{ }^{* *} \mathrm{p}<0.01,{ }^{* * *} \mathrm{p}<0.001$ : significantly different from control group.

$\# \mathrm{p}<0.05, \# \mathrm{p}<0.01, \# \# \mathrm{p}<0.001$ : significantlydifferent from $\mathrm{NaNO}_{3}$.

\section{Non-enzymatic and enzymatic anti-oxidant status}

The concentration of glutathione and Vit $\mathrm{C}$ showed a significant decrease by $-18.87 \%$ and $-38.08 \%$, respectively, in $\mathrm{NaNO}_{3}$ treated group compared to the control (Table 5). The GPx, GST, CAT and SOD antioxidant activities also decreased. In $\mathrm{NaNO}_{3}$ group, GPx, GST, CAT and SOD activities were significantly decreased by $-35.54 \%,-50 \%$, $-25.47 \%$ and $-17.2 \%$, respectively, when compared to the control. These modifications were changed by the co-administration of PSO with $\mathrm{NaNO}_{3}$ in animals as indicated in the significant increase of GPx, GST, CAT and SOD activities compared to that of $\mathrm{NaNO}_{3}$ group (Table 6).

Table 6. Antioxidant enzyme activities (GPx, CAT, SOD and GST) in liver of control and treated rats with $\mathrm{NaNO}_{3}$, $\mathrm{PSO}$ or their combination $\left(\mathrm{NaNO}_{3} / \mathrm{PSO}\right)$ during 28 days.

\begin{tabular}{lcccc}
\hline \multicolumn{1}{c}{ Parameters and treatments } & $\begin{array}{c}\text { Control } \\
(\mathrm{n}=10)\end{array}$ & $\begin{array}{c}\mathrm{NaNO}_{3} \\
(\mathrm{n}=10)\end{array}$ & $\begin{array}{c}\mathrm{PSO} \\
(\mathrm{n}=10)\end{array}$ & $\begin{array}{c}\mathrm{NaNO}_{3} / \mathrm{PSO} \\
(\mathrm{n}=10)\end{array}$ \\
\hline GPx $(\mu \mathrm{mol} \mathrm{GSH} / \mathrm{mg}$ prot. $)$ & $0.8 \pm 0.04$ & $0.52 \pm 0.05^{* *}$ & $0.86 \pm 0.03^{\# \#}$ & $0.74 \pm 0.04^{\#}$ \\
CAT $\left(\mu \mathrm{mol} \mathrm{H} \mathrm{H}_{2} / \mathrm{min} / \mathrm{mg}\right.$ prot. $)$ & $286.24 \pm 13.14$ & $213.34 \pm 8.91^{* *}$ & $295.84 \pm 2.14^{\# \#}$ & $245.94 \pm 10.14^{\#}$ \\
SOD $(\mathrm{U} / \mathrm{mg}$ prot. $)$ & $242.08 \pm 4.28$ & $200.45 \pm 3.29^{* * *}$ & $257.8 \pm 5.78^{\# \#}$ & $224.11 \pm 5.53^{\# \#}$ \\
GST $(\mu \mathrm{mol} \mathrm{C}-\mathrm{DNB} / \mathrm{min} / \mathrm{mg}$ prot. $)$ & $0.08 \pm 0.005$ & $0.04 \pm 0.006^{* *}$ & $0.08 \pm 0.01^{\# \#}$ & $0.08 \pm 0.01^{\#}$ \\
\hline
\end{tabular}

Values are means \pm SEM, n: number of animals ineach group.

${ }^{*} \mathrm{p}<0.05,{ }^{*} \mathrm{p}<0.01,{ }^{* * *} \mathrm{p}<0.001$ : significantly different from control group.

$\# \mathrm{p}<0.05, \# \# \mathrm{p}<0.01, \# \# \mathrm{p}<0.001$ : significantly different from $\mathrm{NaNO}_{3}$.

\section{Histopathological profiles}

The histopathological examination of liver is shown in Table 7 and Fig. 1. In fact, the microscopic observation of the control group revealed a normal architecture (Fig. 1-A). In contrast, $\mathrm{NaNO}_{3}$-treated liver revealed hepatocytes degeneration (black arrow), vein congestion (white arrow), inflammatory cell infiltration (circle) and sinusoi- dal dilatation (Star) (Fig1-B). However, no histological alterations were observed in the livers of PSO group when compared to the control (Fig 1- C). Furthermore, the co-administration of $\mathrm{NaNO}_{3}$ and PSO (Fig 1-D) has reduced the inflammatory cell infiltration, kept normal hepatocytes architecture and lowered the degree of sinusoidal dilatation compared to sodium nitrate treated group. 
Table 7. Semiquantitative scoring of architectural damage on histopathological examination of control and treated rats with $\mathrm{NaNO}_{3}$, $\mathrm{PSO}$ or their combination $\left(\mathrm{NaNO}_{3} / \mathrm{PSO}\right)$ during 28 days.

\begin{tabular}{lcccc}
\hline Treatments & Control & $\mathrm{NaNO}_{3}$ & $\mathrm{PSO}$ & $\mathrm{NaNO}_{3} / \mathrm{PSO}^{2}$ \\
\hline Sinusoidal dilatation & $(-)$ & $(+++)$ & $(-)$ & $(++)$ \\
Inflammatory cells infiltration & $(-)$ & $(+++)$ & $(-)$ & $(+)$ \\
Degeneration of hepatocytes & $(-)$ & $(++)$ & $(-)$ & $(-)$ \\
Vien congestion & $(-)$ & $(+++)$ & $(-)$ & $(++)$ \\
\hline
\end{tabular}

$(-)$ indicates normal, $(+)$ indicates mild, $(++)$ indicates moderate and $(+++)$ indicates severe.
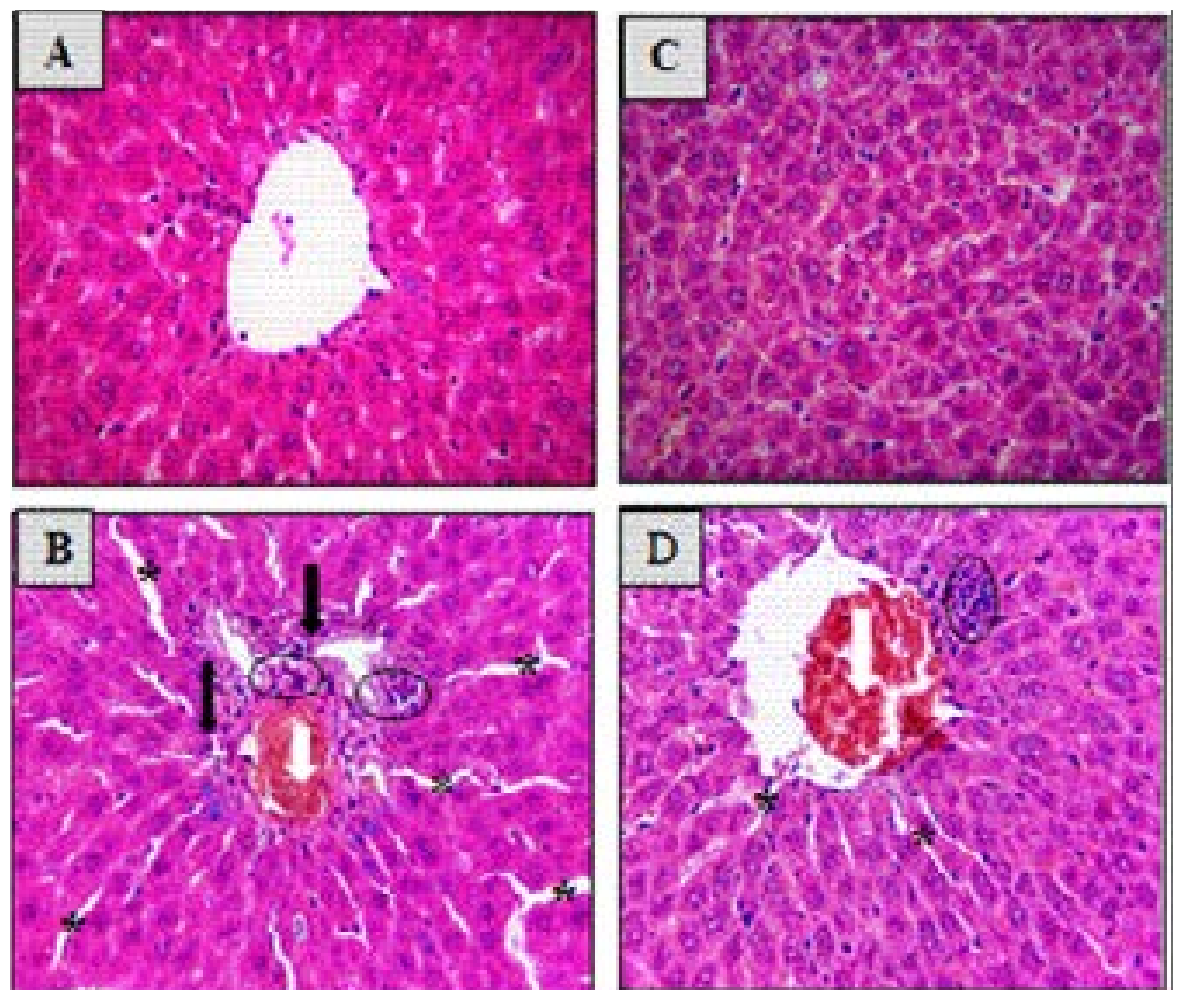

Figure 1. Histological liver sections of controls, with normal architecture, (B) $\mathrm{NaNO}_{3}$ treated group, (C) PSO treated group and (D) $\mathrm{NaNO}_{3} / \mathrm{PSO}$ treated group during 28 days. Optic microscopy: H\&E (X400). Hepatocytes degeneration (black arrow), vein congestion (white arrow), inflammatory cell infiltration (circle), sinusoidal dilatation (Star).

\section{Discussion}

From the above data, pumpkin seed oil seems to contain high amount of polyphenols, flavonoids and tannins. Accordingly, Que et $\mathrm{al}^{32}$ have reported that PSO is rich in phenolic and flavonoid compounds. These components are said to possess many functional groups, including hydroxyl groups, which have very strong anti-oxidant potential $^{33}$. In consequence, polyphenols and flavonoids are able to scavenge hydroxyl radicals, superoxide anion and peroxylipidic radicals ${ }^{34}$. Moreover, it was clearly shown in this study that PSO had a potential antioxidant to scavenge DPPH, phosphomolybdenum and ABTS radical. This is why pumpkin is a plant that has been frequently used as functional food or medicine ${ }^{11}$. Anti-oxidant properties, especially radical scavenging activities, are very important due to the harmful role of free radicals in foods 
and in biological system. DPPH is a stable free radical, which accepts an electron or hydrogen radical to become a stable diamagnetic molecule ${ }^{35}$.

This research work showed that the treatment of rats with sodium nitrate induced a significant decrease in body weight and daily food consumption, which may be due to the toxicity induced by this toxicant. This result is in agreement with that obtained previously ${ }^{8,36}$. Other data suggested that nitrate can exert its effect on the body weight through increasing protein catabolism ${ }^{37}$. Therefore, the decreased serum and tissue proteins may indicate the enhanced protein catabolism associated with weight loss ${ }^{1}$. Although the treatment of rats with PSO had no significant effect on body weights ${ }^{14}$, it had a significant decrease in food intake and water consumption, but it normalises serum total proteins. The decrease in food intake and water consumption are probably due to the presence of tannins and gallic acid in pumpkin seed oil, which can decrease food ingestion and the growth rate ${ }^{34}$. Furthermore, the increase of the total proteins perhaps is due to the fact that pumpkin seeds (Cucurbita spp.) are rich in mineral, calories and proteins ${ }^{38}$.

The exposure of rats to $\mathrm{NaNO}_{3}$ increased glycaemia and nitric oxide serum levels, which are in accordance with the study of El-wakf et al, who demonstrated that hyperglycaemia could be a cause of insulin deficiency ${ }^{1}$. However, the increased generation of NO could lead to tissue damage, which can have a direct effects mediated by NO itself or an indirect effect mediated by reactive nitrogen species ${ }^{1}$. Yet, the co-administration of PSO to treated rats resulted in significant improvement in serum level of the previous parameters, which are in good agreement with the earlier studies ${ }^{39,40}$.

The exposure to $\mathrm{NaNO}_{3}$ is also characterized by the depletion of RBCs, HT and $\mathrm{Hb}$ and increased WBC counts. The significant reduction in $\mathrm{RBC}$ and $\mathrm{Hb}$ is probably due to the effect of the free radicals generated by nitrate on the red cells when certain free radicals, as $\mathrm{O}_{2}$.- $^{-}$and $\mathrm{OH}$, are very reactive species able to cause membrane lipid damage. Moreover, in the presence of strong concentrations of these radicals, haemoglobin can easily oxidised $^{41,42}$. Furthermore, PSO co-administration in rats' was found to keep the investigated parameters within their physiological ranges. Such effect might be related to the phenolic compounds, which act to scavenge the free radicals. Soltan ${ }^{38}$ showed an increase in RBC, Hb and HT levels in rats fed with pumpkin powder seed and ascorbic acid. Contrary, Kuku et $\mathrm{al}^{43}$ showed a lowering in WBC counts in animals fed unprocessed and under-processed fluted pumpkin seeds.

Our results demonstrated a significant increase in serum AST, ALT, LDH and ALP activities of $\mathrm{NaNO}_{3}$ treated rats. The increases in enzymes activities may be owed to hepatic cell damage or dysfunction, which results in the leakage of these enzymes from hepatocytes into the blood and/or to the disturbance in the balance between biosynthesis and degradation'. The present results are in agreement with those obtained previously ${ }^{8}$. Meanwhile, $\mathrm{NaNO}_{3}$ treatment also caused a significant increase in serum bilirubin levels, emanating from the toxic effect of nitrates by destructing red blood cells. However, serum bilirubin increases could also be of hepatic origin (hepatitis, cirrhosis). Indeed, Al-Ezzy et $\mathrm{al}^{5}$ showed a rise in the serum total bilirubin level of mice treated with sodium nitrate. In fact, the co-administration of PSO was proven to ameliorate the levels of all studied biochemical parameters. Our findings are consistent with those of Abou Seif ${ }^{11}$ who reported that pre-treatment of rats with PSO improved the serum total proteins and bilirubin levels and the activities of LDH, ALT and ALP. The administration of proteins extracted from pumpkin seeds after CCl4 intoxication had significantly reduced the $\mathrm{LDH}$, ALT, AST, and ALP activities ${ }^{44}$. The possible explanation is that PSO had hepathoprotective effects on nitrate toxicity, by scavenging free radicals, quenches their damaging effects and remedies liver injury.

Among the various oxidative modifications of amino acids in proteins, PCO formation may be an early marker for protein oxidation ${ }^{7}$. From this information, we proceeded to assay MDA, PCO and AOPP levels in liver tissue. The actual data showed an increase of all these parameters in $\mathrm{NaNO}_{3}$ group in the presence of sodium nitrate, which induces the formation of free radicals that attack lipids and proteins of hepatic cells. In parallel, Bouaziz-ketata et $\mathrm{al}^{8}$ have shown that the administration of $\mathrm{NaNO}_{3}$ caused a remarkable rise of rat liver MDA contents. Owing to the MDA cytotoxicity and inhibitory action on cellular protective enzymes, it is suggested to act as a tumour promoter ${ }^{45}$. 
The antioxidant and other cell redox state modulating enzyme systems act as the first-line defense against ROS in all cellular and extra cellular compartments ${ }^{46}$. Oxidative damage is aggravated by the decrease in antioxidant enzymes activities as SOD, CAT, GPx and GST, which act as free radical scavengers in conditions associated with oxidative stress ${ }^{47}$. More specifically, SOD is the first line of antioxidant defense, which accelerates the dismutation of superoxide ion into less toxic $\mathrm{H}_{2} \mathrm{O}_{2}$. The latter is subsequently converted into nontoxic water and oxygen molecules by the action of $\mathrm{CAT}^{48}$. Nevertheless, GPx plays a pivotal role in $\mathrm{H}_{2} \mathrm{O}_{2}$ catabolism and GST acts a key role in cellular detoxification ${ }^{41,49}$. It was found that small deviations in physiological concentrations may have dramatic effects on the resistance of cellular lipids, proteins and DNA to oxidative damage ${ }^{49}$. Moreover, the treatment of rats with sodium nitrate lowered the levels of SOD, CAT and GPx activities ${ }^{8}$.

In addition, a reduction of Vit C and GSH levels in $\mathrm{NaNO}_{3}$ treated rats were recorded in this study. It is postulated that the hepatoprotective effect of vitamin $\mathrm{C}$ is associated with its antioxidative property by decreasing lipid peroxidation either directly or indirectly through the regeneration of vitamin $\mathrm{E}^{5}$. Moreover, GSH, the most abundant thiol in the cell, is considered as the major cellular redox buffer ${ }^{46}$. The decrease of GSH level of liver tissue can be provoked by the toxic effect of $\mathrm{NaNO}_{3}$, by blocking its thiol function with direct conjugation of nitrate and/or its metabolite, or through the inhibition of glutamyl-cysteine-synthetase activity. Furthermore, decreased hepatic GSH level was noticed after the treatment of rats with sodium nitrate ${ }^{8}$.

In parallel, the treatment of rats with pumpkin seed oil have not disturbed the concentrations of MDA, PCO and AOPP. In addition, PSO supplementation ameliorated the non-enzymatic GSH and Vit $\mathrm{C}$ and the enzymatic antioxidant activities of SOD, GST, CAT and GPx. This rebalance of the antioxidant status is certainly related to the high antioxidant potential of PSO that contains polyphenols, flavonoids acids and tannins detected in its phytochemical study. The PSO is also known to contain high amounts of tocopherols and selenium, which are powerful anti-oxidants. The latter are suggested to provide good tissue oxygenation ${ }^{50}$. On the same way, the pre-treatment of rats with pumpkin seed oil induced a noticeable re- duction in lipid peroxidation and boosted the antioxidant status represented by hepatic CAT, GST and $\mathrm{GSH}^{11}$. Moreover, hepatoprotection was observed through the decrease of MDA level after supplementation of flax and pumpkin seed mixture ${ }^{53}$. Makni et al. (2011) $)^{39}$ also showed a rise in anti-oxidant enzymes activities and GSH level in diabetic rats supplemented with flax and pumpkin seed. Likewise, polyunsaturated fatty acids (linoleic acid and $\alpha$ -linoleic acid) have been shown to display protective roles against lipid peroxidation, by increasing the levels of several cellular antioxidants, such as ascorbic acid, $\alpha$-tocopherol and $\mathrm{GSH}^{11}$. Furthermore, the essential trace mineral zinc in pumpkin seeds was suggested to neutralize free radical generation, or directly occupy the iron or copper binding sites of lipids, proteins, and DNA molecules ${ }^{51}$.

In fact, the relative and absolute liver weight of rats treated by nitrate was significantly increased. This increase may be due to the toxic effect of nitrate or its metabolites, which could induce liver injury and hepatocytes necrosis. These results agree well with those of Ogur et $\mathrm{al}^{52}$ who showed that nitrate intake caused hepatomegaly. In the present study, the liver histology of $\mathrm{NaNO}_{3}$-treaded rats showed an infiltration of inflammatory cell, vein congestion, hepatocytes degeneration, and sinusoidal dilatation, which may be due to the formation of free radicals, protein carboxylation and lipids peroxidation that caused plasma membrane destruction. Therefore, the histopathological study of liver tissues confirms the changes of the previously studied parameters. In nitrate-treated rats, liver showed a vein inflammation, cellular degeneration and cell necrosis ${ }^{8}$. Fortunately, PSO co-administration showed only slight histological alteration, by reducing inflammatory cell infiltration and lowering the degree of sinusoidal dilatation. This result is in accordance with those of Makin et $\mathrm{a}^{53}$ who showed a normal architecture of rat liver tissues fed with cholesterol and pumpkin seed mixture.

\section{Conclusion}

The results obtained in this study revealed the presence of phenolic, flavonoids, tannins and antioxidant scavengers in pumpkin seed oil. However, PSO co-administration with sodium nitrate decreased liver injury, and maintained haematological, biochemical and oxidative stress parameters of rats within the physiological ranges. This finding suggests the possible protective roles of pump- 
kin seed oil towards the cytotoxicity induced by sodium nitrate.

\section{Acknowledgments}

The present work was supported by DG-RSDT (General Directorate of Scientific Research and Technological Development-Algeria) via the Laboratory of Biochemistry and Environmental Toxicology, Faculty of Sciences, University of Badji Mokhtar-Annaba, Algeria. In addition, the authors would like to thank the Algerian and Tunisian Ministries of Higher Education and Scientific Research for the support of this research work via the Algero-Tunisian project. They also wish to extend their thanks to Mrs. Leila MAHFOUDHI, Emeritus Teacher of English at the Sfax Faculty of Science, for having proofread and polished the language of the manuscript.

\section{Conflict of interest}

None declared.

\section{References}

1. El-Wakf AM, Hassan HA, Mahmoud AZ, Habza MN. Fenugreek potent activity against nitrate-induced diabetes in young and adult male rats. Cytotechnology. 2015; 67(3): 437-447. DOI: 10.1007/s10616-014-9702-7.

2. Anwar M, Mohamed N. Amelioration of liver and kidney functions disorders induced by sodium nitrate in rats using wheat germ oil. Journal of Radiation Research and Applied Sciences. 2015; 8(1):77-83. DOI: 10.1016/j.jrras.2014.11.004.

3. Aly HA, Mansour AM, Abo-Salem OM, Abd-Ellah HF, Abdel-Naim AB. Potential testicular toxicity of sodium nitrate in adult rats. Food Chem Toxicol. 2010; 48(2): 572-578. DOI: 10.1016/j.fct.2009.11.034.

4. WHO. Nitrate and nitrite in drinking-water. Background document for development of WHO Guidelines for Drinking- water Quality. Geneva, World Health Organization. 2007.

5. Al-Ezzy AIA, Hameed MS, Jalil WI, Mohamad WM. Pathophysiological Effects of Vitamin C and E-Selenium Combination on Lipid Profile and Serum Glucose of Experimentally Induced Sodium Nitrate Intoxication in Mice. Research Journal of Pharmacentical Biological and Chemical Sciences. 2016; 7(2):958-964. DOI:

6. Thabit S, Alrawi J. The Effect of Nitrate on some Biochemical Parameters of Rabbits and Ameliorate its Effect by using Vitamin E and Rosemary (Rosmarinus Officinalis). American Journal of Animal and Veterinary Sciences. 2016; 11 (4):145.150. DOI: 10.3844/ajavsp.2016.145.150.
7. Chaabane M, Koubaa M, Soudani N, Elwej A, Grati M, Jamoussi K, Boudawara T, Chaabouni SE, Zeghal N. Nitraria retusa fruit prevents penconazole-induced kidney injury in adult rats through modulation of oxidative stress and histopathological changes. Pharmaceutical Biology. 2017; 55: 1061-1073. DOI: 10.1080/13880209.2016.1278455.

8. Bouaziz-Ketata H, Ben Salah G, Ben Salah H, Marrekchi R, Jamoussi K, Boudawara T, Fakhfekh F, Zeghal N. Nitrate-induced biochemical and histopathological changes in the liver of rats: ameliorative effect of Hyparrhenia hirta. Biomedical and Environmental Sciences. 2014; 27(9):695-706. DOI: 10.3967/bes2014.105.

9. Bouasla I, Bouasla A, Boumendjel A, Messarah M, Abdennour C, Boulakoud MS, El Feki A. Nigella sativa Oil Reduces Aluminium Chloride-Induced Oxidative Injury in Liver and Erythrocytes of Rats. Biol Trace Elem Res. 2014. DOI 10.1007/s12011-014-0114-5.

10. Nkang A, Omokaro D, Egbe A, Amanke G. Variations in fatty acid proportions during desiccation of Telfairia occidentalis seeds harvested at physiological and agronomic maturity. African Journal of Biotechnology. 2003; 2(2): 33-39. DOI: 10.5897/AJB2003.000-1006.

11. Abou Seif SH. Ameliorative effect of pumpkin oil (Cucurbita pepo L.) against alcohol-induced hepatotoxicity and oxidative stress in albino rats. Beni Suef University. Journal of Basic and Applied Sciences. 2014; 3:178-185. DOI: 10.1016/j.bjbas.2014.08.001.

12. Fu CL, Shi H, Li QH. A Review on Pharmacological Activities and Utilization Technologies of Pumpkin. Plant Foods Hum. 2006. Nutr 6:73-80. DOI: 10.1007/s11130006-0016-6.

13. Elfiky S, Elelaimy I, Hassan A, Ibrahim H, Elsayad R. Protective effect of pumpkin seed oil against genotoxicity induced by azathioprine. The Journal of Basic and Applied Zoology. 2012; 65(5): 289-298. DOI: 10.1016/j. jobaz.2012.10.010.

14. Bardaa S, Ben Halima N, Aloui F, Ben Mansour R, Jabeur H, Bouaziz M, Sahnoun Z. Oil from pumpkin (Cucurbita pepo L.) seeds: evaluation of its functional properties on wound healing in rats. Lipids in Health and Disease. 2016; 15(1): 73. DOI: 10.1186/s12944-016-02370.

15. Bouaziz M, Grayer RJ, Simmonds MS, Damak M, Sayadi S. Identification and antioxidant potential of flavonoids and low molecular weight phenols in olive cultivar Chemlali growing in Tunisia. Journal of Agricultural and Food Chemistry. 2005; 53(2): 236-241. DOI: 10.1021/ jf048859d.

16. Zhishen J, Mengcheng T, Jianming W. The determiAfrican Health Sciences Vol 20 Issue 1, March, 2020 
nation of flavonoid contents in mulberry and their scavenging effects on superoxide radicals. Food chemistry. 1999; 64(4): 555-559. DOI: 10.1016/S0308-8146(98)00102-2. 17. Julkunen-Tiitto, R. Phenolic constituents in the leaves of northern willows: methods for the analysis of certain phenolics. Journal of Agricultural and Food Chemistry. 1985; 33(2): 213-217. DOI: 10.1021/jf00062a013.

18. Bouaziz M, Feki I, Ayadi M, Jemai H, Sayadi S. Stability of refined olive oil and olive pomace oil added by phenolic compounds from olive leaves. European Journal of Lipid Science and Technology. 2010; 112(8): 894-905. DOI: 10.1002/ ejlt.200900166.

19. Prieto P, Pineda M, Aguilar M. Spectrophotometric quantitation of antioxidant capacity through the formation of a phosphomolybdenum complex: specific application to the determination of vitamin E. Analytical Biochemistry. 1999; 269(2): 337-341. DOI:10.1006/ abio.1999.4019.

20. Turoli D, Testolin G, Zanini R, Bellu R. Determination of oxidative status in breast and formula milk. Acta Paediatrica. 2004; 93(12): 1569-1574. DOI:10.1111/j.1651-2227.2004.tb00845.x.

21. Green LC, Wagner DA, Glogowski J, Skipper PL, Wishnok JS, Tannenbaum SR. Analysis of nitrate, nitrite, and $[15 \mathrm{~N}]$ nitrate in biological fluids. Analytical Biochemistry. 1982; 126(1): 131-138. DOI:10.1016/00032697(82)90118-X.

22. Esterbauer H, Gebicki J, Puhl H, Jürgens G. The role of lipid peroxidation and antioxidants in oxidative modification of LDL. Free Radical Biology and Medicine1. 1992; 3(4): 341-390. DOI: 10.1016/0891-5849(92)90181-F.

23. Reznick AZ, Packer L. [38] Oxidative damage to proteins: Spectrophotometric method for carbonyl assay. Methods in Enzymology. 1994; 233: 357-363. DOI: 10.1016/ S0076-6870(94)33041-7.

24. Kayali R, Çakatay U, Akçay T, Altuğ T. Effect of $\alpha$-lipoic acid supplementation on markers of protein oxidation in post-mitotic tissues of ageing rat. Cell Biochemistry and Function. 2006; 24(1):79-85.

25. Flohe L, Gunzler WA. Analysis of glutathione peroxidase. Methods Ensymol. 1984; 105: 114-121.

26. Habig WH, Pabst MJ, Jakoby WB. Glutathione $\mathrm{S}$-transferases the first enzymatic step in mercapturic acid formation. Journal of Biological Chemistry. 1974; 249(22): 7130-7139.

27. Aebi H. Catalase in vitro. Method Ensymol. 1984; 105:121-126. DOI: 10.1016/S0076-6879(84)05016-3.

28. Beyer WF, Fridovich I. Assaying for superoxide dis- mutase activity: some large consequences of minor changes in conditions. Analytical Biochemistry. 1987; 161: 559-566. DOI: 10.1016/0003-2697(87)90489-1.

29. Ellman GL. Tissue sulfhydryl groups. Archives of Biochemistry and Biophysics. 1959; 82(1): 70-77. DOI: 10.1016/0003-9861(59)90090-6.

30. Jollow D, Mitchell J, Zampaglione NA, Gillette J. Bromobenzene-induced liver necrosis. Protective role of glutathione and evidence for 3, 4-bromobenzene oxide as the hepatotoxic metabolite. Pharmacology. 1974; 11(3): 151-169. DOI: 10.1159/000136485.

31. Jacques-Silva MC, Nogueira CW, Broch LC, Flores EM, Rocha JBT. Diphenyl diselenide and ascorbic acid changes deposition of selenium and ascorbic acid in liver and brain of mice. Basic and Clinical Pharmacology and Toxicology. 2001; 88(3):119-125.

32. Que F, Mao L, Fang X, Wu T. Comparison of hot air-drying and freeze-drying on the physicochemical properties and antioxidant activities of pumpkin (Cucurbita moschata Duch.) flours. International Journal of Food Science and Technology. 2008; 43(7): 1195-1201. DOI: 10.1111/j.1365-2621.2007.01590.x.

33. Sopan BA, Vasantrao DN, Ajit SB. Total phenolic content and antioxidant potential of cucurbita maxima (pumpkin) powder. International Journal of Pharmacentical Sciences and Research. 2015; 5(5): 1903-1907.

34. Chekchaki N, Khaldi T, Rouibah Z, Rouag M, Sekiou O, Messarah M, Boumendjel A et al. Anti-Inflammatory and Antioxidant Effects of Two Extracts from Pistacia lentiscus in Liver and Erythrocytes, in an Experimental Model of Asthma. International Journal of Pharmacentical Sciences Review and Research. 2017; 42(1): 77-84.

35. Pan Y, Wang K, Huang S, Wang H, Mu X, Hu C, Ji X, Zhang J, Huang F. Antioxidant activity of microwave-assisted extract of longan (Dimocarpus Longan Lour.) peel. Food Chemistry. 2008; 106: 1264-1270. DOI: 10.1016/j.foodchem.2007.07.033.

36. Baş H, Kalender Y. Nephrotoxic effects of lead nitrate exposure in diabetic and nondiabetic rats: involvement of oxidative stress and the protective role of sodium selenite. Environmental Toxicology. 2016; 31(10): 1229-1240. DOI: $10.1002 /$ tox.22130.

37. Al-Ayed MI. Toxicity of drinking water with different nitrate levels. J Egy Ger Soc Zool. 2000; 31: 197-209.

38. Soltan SS. The protective effect of soybean, sesame, lentils, pumpkin seeds and molasses on iron deficiency anemia in rats. World Appl Sci J2. 2013; 3: 795-807. DOI: 10.5829/idosi.wasj.2013.23.06.13100. 
39. Makni M, Fetoui H, Gargouri NK, Garoui E, Zeghal N. Antidiabetic effect of flax and pumpkin seed mixture powder: effect on hyperlipidemia and antioxidant status in alloxan diabetic rats. Journal of Diabetes and its Complications. 2011; 25(5): 339-345. DOI: 10.1016/j.jdiacomp.2010.09.001.

40. Abdel-Reheim ES, Rashad AR, Taha ME. Curcubita pepo seed oil ameliorative effects on histological and biochemical changes in rat epileptic model. International Journal of Advanced Research. 2015. 3(7): 535-564.

41. Klibet F, Boumendjel A, Khiari M, El Feki AF, Adennour C, Messarah M. Oxidative stress-related liver dysfunction by sodium arsenite: Alleviation by Pistacia lentiscus oil. Pharm Biol . 2015; 1-10. DOI: 10.3109/13880209.2015.1043562.

42. Bouaziz-Ketata H, Ben Salah G, Mahjoubi A, Aidi Z, Kallel C, Kammoun H, Fakhfakh F, Zeghal N. Hyparrhenia hirta : A potential protective agent against hematotoxicity and genotoxicity of sodium nitrate in adult rats. Environmental Toxicology. 2015; 30(11): 1275-1284. DOI: 10.1002/tox.21998.

43. Kuku A, Etti U, Ibironke I. Processing of fluted pumpkin seeds, Telfairia occidentalis (Hook F) as it affects growth performance and nutrient metabolism in rats. African Journal of Food, Agriculture, Nutrition and Development. 2014; 14(5): 1992-2014.

44. Nkosi CZ, Opoku AR, Terblanche SE. Effect of pumpkin seed (Cucurbita pepo) protein isolate on the activity levels of certain plasma enzymes in CCl4-induced liver injury in lowprotein fed rats. Phytother Res. 2005; 19: (341e5). DOI: 10.1002/ptr.1685.

45. Hassan, H.A., Ghareb, N. E., and Azhari, G. F., 2017. Antioxidant activity and free radical-scavenging of cape gooseberry (Physalis peruviana L.) in hepatocellular carcinoma rats model. Hepatoma Research, 3(2), 27.

46. Lafi B, Chaabane M, Elwej A, Grati M, Jamoussi K, Mnif H, Boudawara T, Bouaziz-Ketata H, Zeghal N. Effects of co-exposure to imidacloprid and gibberlic acid on redox status, kidney variables and histopathology in adult rats. Archives of Physiology and Biochemistry. 2017; 1-10. DOI: 10.1080/13813455.2017.1371195.

47. Blokhina O, Virolainen E, Fagerstedt KV. Antioxidants, oxidative damage and oxygen deprivation stress: a review. Annals of Botany. 2003; 91(2): 179-194. DOI: $10.1093 / \mathrm{aob} / \mathrm{mcf118}$.

48. Elwej A, Ghorbel I, Chaabane M, Soudani N, Mnif H, Boudawara T, Zeghal N, Sefi M. Zinc and selenium modulate barium-induced oxidative stress, cellular injury and membrane-bound ATPase in the cerebellum of adult rats and their offspring during late pregnancy and early postnatal periods. Arch Physiol Biochem. 2017; 1-10. DOI: 10.1080/13813455.2017.1392579.

49. Ktari N, Bkhairia I , Nasri R, Ben Abdallah Kolsi R, Ben Slama-Ben Salem R, Ben Amara I, Zeghal N, Ben Salah B, Ben Salah R, Nasri M. Zebra blenny protein hydrolysates as a source of bioactive peptides with prevention effect against oxidative dysfunctions. Food Research International. 2017; 100: 423-432. DOI: 10.1016/j. foodres.2017.07.040.

50. Al-Zuhair H, Abd El-Fattah AA, El-Sayed MI. Pumpkin-Seed Oil Modulates the Effect of Felodipine and Captopril in Spontaneously Hypertensive rats. Pharmacological Research. 2000; 41: 555-563. DOI: 10.1006rphrs.1999.0622.

51. Shaban A, Sahu RP. Pumpkin Seed Oil: An Alternative Medicine. International Journal of Pharmacognosy and Phytochemical Research. 2017; 9(2). DOI:10.25258/phyto. v9i2;8066.

52. Ogur R, Coskun O, Korkmaz A, Oter S, Yaren H, Hasde M. High nitrate intake impairs liver functions and morphology in rats; protective effects of $\alpha$-tocopherol. Environmental toxicology and Pharmacology. 2005; 20(1): 161 166. DOI: $10.1016 /$ j.etap.2004.12.051.

53. Makni M, Fetoui H, Gargouri N, Garoui EM, Jaber H, Makni J, Boudawara T, Zeghal N. Hypolipidemic and hepatoprotective effects of flax and pumpkin seed mixture rich in $\omega-3$ and $\omega-6$ fatty acids in hypercholesterolemic rats. Food and Chemical Toxicology. 2008; 64 (12):37143720. DOI: $10.1016 /$ j.fct.2008.09.057. 